\title{
Differences in severity of mastitis and the pathogens causing various oxidative product levels
}

\author{
Witaya Suriyasathaporn $^{1 *}$, Teera Chewonarin ${ }^{2}$, Usanee Vinitketkumnuen ${ }^{2}$ \\ ${ }^{1}$ Department of Food Animal Clinics, Faculty of Veterinary Medicine, Chiang Mai University, Chiang Mai, Thailand \\ ${ }^{2}$ Department of Biochemistry, Faculty of Medicine, Chiang Mai University, Chiang Mai, Thailand \\ Email: switaya@chiangmai.ac.th
}

Received 27 June 2012; revised 28 July 2012; accepted 17 August 2012

\begin{abstract}
Differences in severity of mastitis and their causing pathogens might be associated with oxidative product levels occurring during the inflammatory process in infected udders. The objectives of this study were to determine the relationship of oxidative product levels, using malondialdehyde (MDA) as a marker on both mastitis severity and its causing pathogens. Quarter milk samples of all lactating cows in the selected farms were primarily tested for mastitis severity levels including clinical and subclinical mastitis. All quarter milk samples from mastitis cows were separately collected for MDA measurement and bacteriological analyses. Results showed that MDA in clinical mastitis quarters was highest in comparison to subclinical mastitis and healthy quarters. MDA in milk samples with Strep. uberis and coagulase negative staphylococci was higher than in milk samples without any pathogens $(P<0.05)$. In conclusion, differences in both severity of mastitis and mastitis pathogens were associated with differences of oxidative products in infected udders.
\end{abstract}

Keywords: Malondialdehyde; Bacterial Pathogens; Severity of Mastitis; Dairy Cows

\section{INTRODUCTION}

Mastitis, causing a decrease in milk quality, is an important public health problem worldwide, in humans as well as in domesticated animals. The major cause of mastitis is from bacterial intramammary infections (IMI) for example staphylococci, streptococci, and gram-negative bacteria [1]. In Thailand, pathogens causing mastitis were mostly environmental streptococci and coagulase negative staphylococci $[2,3]$. The distribution of mastitis pathogens may differ between clinical and subclinical mastitis: clinical mastitis can be caused by pathogens

${ }^{*}$ Corresponding author. that are present for a short duration and produce obvious clinical signs, whereas subclinical mastitis can be caused by pathogens that are present for longer periods of time and produce negligible clinical signs.

After bacterial intramammary infection, udder defense acts to eliminate invading pathogens by phagocytes. One of the most important processes in udder defense is the bactericidal process that mediates by generating some oxidative products to kill invading microorganisms. Overproduction of oxidative products, such as nitric oxide (NO), is associated with host-mediated defense mechanisms, immunomodulation and autotoxicity that occur during microbial infection and inflammation in certain cells [4]. After IMI, neutrophils move rapidly from the blood stream into the infected quarter [5], and this subsequently causes an increase of somatic cell count (SCC) in milk of IMI quarter. Previous studies have shown the relationship between SCC and malondialdehyde (MDA), a marker of oxidative product in defense mechanism, in both quarter milk [6] and bulk tank milk [7]. In addition, a recent study showed that MDA was a mediator of a decreased milk yield in cows with high SCC [8]. Although, overproduction of oxidative products was related to cell autotoxicity resulting in decrease of milk yield, the knowledge on relationships of either severity of mastitis or pathogens causing them on levels oxidative production after infection was limitation. Therefore, it is possible that the production of MDA might be related to the severity of mastitis and its pathogens.

Therefore the objectives of this study were to determine the differences of levels of oxidative product, using MDA as a marker on both severity of mastitis and their causing pathogens in infected udders.

\section{MATERIALS AND METHODS}

\subsection{Experimental Design}

Small-holder dairy farms with average bulk tank somatic cell counts $(\mathrm{BMSCC})>500,000 \mathrm{cells} / \mathrm{ml}$ were selected. For general farm management, cows were housed in 
tied-stall barns, fed post-harvest corn stem and straw ad lib, and concentrates according to their milk production. The vast majority of the cows were crossbred HolsteinFriesian. Quarter milk samples of all lactating cows in the selected farms were primarily tested for mastitis severity levels including clinical and subclinical mastitis. Cows with either clinical signs at udder, abnormal milk characteristics or CMT $\geq+1$ in at least one quarter were defined as mastitis cows and then were included into the study. Milk samples of all quarters from the selected cows were separately collected with aseptic techniques in accordance with National Mastitis Council guidelines [9]. The samples were kept in a cool temperature and were transported to the Laboratory immediately for bacterial identification.

\subsection{Microbiological Analyses}

Milk samples $(0.01 \mathrm{~mL})$ were plated on $5 \%$ bovine blood agar. Preliminary bacterial identification was determined by colony morphology, hemolysis, and Gram staining. Samples were regarded as positive for environmental pathogens if a minimum of $1000 \mathrm{cfu}$ of the respective pathogen was determined. For Strep. agalactiae and Staph. aureus, a minimum of $100 \mathrm{cfu}$ was required. Staph. aureus was differentiated from other Staph. spp., the socalled coagulase negative staphylococcus (CNS), using hemolytic patterns and coagulase reaction with rabbit plasma. Streptococci were differentiated by a commercial test kit (API 20 Strep, BioMerieux, Macy-I'Etoile, France). Gram-positive, catalase positive, pleomorphic coccobacilli were identified as Corynebacterium spp. Gram-negative bacteria were identified using culture morphology on MacConkey agar (Merk, Germany), lactose fermentation, motility and reaction in triple sugar iron. Other colony types were grouped as other microorganisms.

\subsection{Measurement of Milk MDA}

After SCC measurement, milk MDA was measured by the modified Smith's method described by Santos and colleagues [10]. Briefly, one hundred microliters of milk sample were properly mixed with $1 \mathrm{ml}$ of trichloroacetic acid with a vortex mixer. Afterwards $400 \mathrm{ml}$ of thiobarbituric acid was added. The mixture was boiled for 30 min and subsequently cooled down by tap water. The solution was quadruplicate analyzed by UV spectrophotometry at $532 \mathrm{~nm}$ against its blank reaction mixture.

\subsection{Statistical Analysis}

One-way analysis of variance (ANOVA) was used to determine the relationship between MDA and either mastitis severity levels or pathogens causing mastitis. For mastitis severity, an average MDA of milk samples from healthy quarters was compared to those from subclinical and clinical mastitis cows. For the pathogens, an average MDA of milk samples from quarters without bacterial isolates was compared with those with each of the bacterial isolates. The levels were considered significantly different at $\mathrm{P}<0.05$.

\section{RESULTS}

A total of 246 quarter milk samples from 63 mastitis cows from 16 small-holder dairy farms were used. All clinical mastitis cows $(n=32 \%$ or $50.79 \%)$ included 24 cows with abnormal milk, 6 cows with clinical systemic signs, and 2 cows with both. At quarter levels, 138 $(58.0 \%), 62(26.0 \%)$ and $38(16.0 \%)$ quarters were classified as healthy, subclinical mastitis, and clinical mastitis, respectively. Numbers and percentages of isolates separated for their severity of mastitis are shown in Table 1. Staphylococci other than St. aureus gave the highest percentages in both subclinical $(22.58 \%)$ and clinical mastitis $(44.74 \%)$ in this study. Other bacteria and Strep. agalactiae had very few data, and were excluded from analyses.

Averages, maximum and minimum values of MDA in this study were 1708, 1036, and 3274 ppb, respectively. Averages of MDA separated for the specified isolates or severity of mastitis were shown in Figures 1(A) and (B), respectively. From univariate analyses, results show that differences of mastitis pathogens or severity of mastitis were related to MDA concentrations $(\mathrm{P}<0.05)$. Milk from clinical mastitis quarters had highest MDA concentrations, and significantly differed from milk from both healthy and subclinical mastitis udders, respectively (Figure 1(A)). MDA from milk samples with CNS and Strep. uberis was significantly higher compared to MDA from milk sample with no growth. No other pairwises difference was found (Figure 1(B)). Results from multivariable model showed that only severity of mastitis was associated with MDA concentrations $(\mathrm{P}<0.05)$.

\section{DISCUSSION}

This is the first report on the relationship between severity of bovine mastitis and oxidative production in infected udders. As expected, severity of mastitis was highly associated with concentrations of MDA (Figure 1(A)). In our previous study, MDA was correlated with levels of somatic cell counts [6]. In our study, subclinical mastitis was determined by the result of CMT score. It has been established that CMT score is positively correlated to levels of somatic cell counts [11]. In clinical mastitis cases, various cell types in the quarter produce abundant soluble factors, such as cytokines, which cause clinical signs of mastitis. As expected, clinical mastitis quarters had highest MDA concentrations. This might be 
Table 1. Numbers and percentages ${ }^{1}$ of bacterial isolates separated for their severity of mastitis 1 from 63 mastitis cows from 16 smallholder dairy farms in Thailand.

\begin{tabular}{lcccccc}
\hline & \multicolumn{2}{c}{ Healthy } & \multicolumn{2}{c}{ Subclinical mastitis } & \multicolumn{2}{c}{ Clinical mastitis } \\
\cline { 2 - 7 } Isolate & Number & $\%$ & Number & $\%$ & Number & $\%$ \\
\hline Staphylococcus aureus & 3 & 2.17 & 3 & 4.84 & 1 & 2.63 \\
Staphylococcus spp. & 9 & 6.52 & 14 & 22.58 & 17 & 44.74 \\
Streptococcus agalactiae & 0 & 0.00 & 2 & 3.23 & 0 & 0.00 \\
Streptococcus uberis & 1 & 0.72 & 4 & 6.45 & 3 & 7.89 \\
Corynebacterium spp. & 20 & 14.49 & 8 & 12.90 & 5 & 13.16 \\
Coliform bacteria & 0 & 0.00 & 3 & 4.84 & 5 & 13.16 \\
Other bacteria & 0 & 0.00 & 3 & 4.84 & 2 & 5.26 \\
No growth & 105 & 76.09 & 25 & 40.32 & 5 & 13.16 \\
\hline
\end{tabular}

${ }^{1}$ Percentages of isolates within groups; ${ }^{2}$ Severities of mastitis were classified into three groups: healthy quarter (no clinical signs with negative results on CMT tests), subclinical mastitis (no clinical signs with a positive CMT), clinical mastitis (abnormal milk with appearance of clots in milk or wateriness and/or acute swelling of gland with fever).

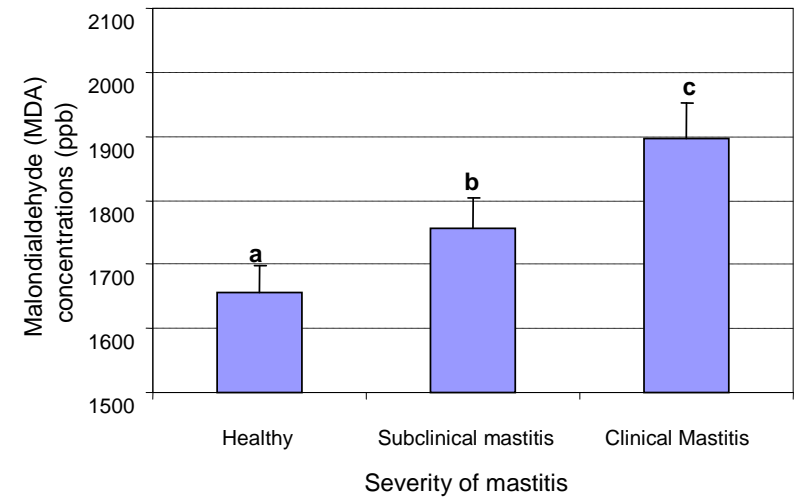

(A)

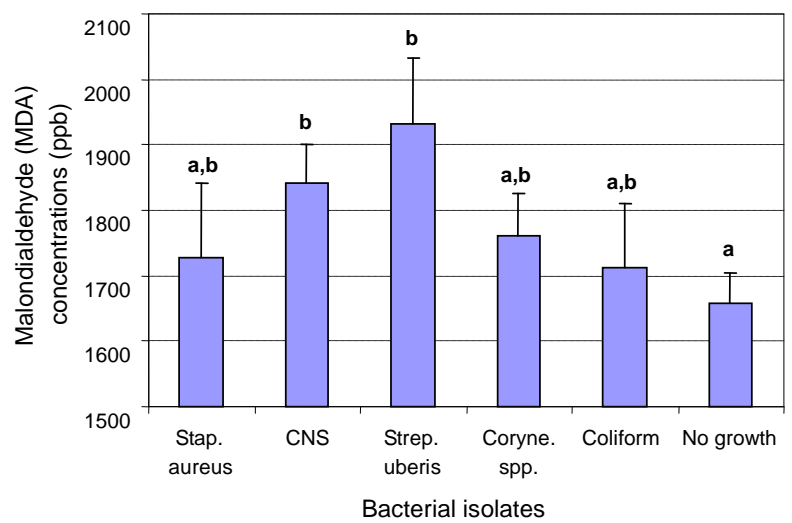

(B)

Figure 1. Least square means of MDA concentrations from quarter milk samples of mastitis cows in Chiang Mai province, in June 2006: (A) MDA concentration separated by severity of mastitis $(\mathrm{n}=246)$ and $(\mathrm{B})$ MDA concentrations separated by isolates $(\mathrm{n}=$ 203). a, b, c Overall MDA values for each isolate without common superscript differ significantly $(\mathrm{P}<0.05)$.

caused by the higher levels of udder defence mechanism. The PMN generates superoxide $\left(\mathrm{O}_{2}^{-}\right)$by the NADPHdependent oxidase to kill invading microorganisms [12]. Although essential for survival, inappropriate or excessive oxidative reaction in the bactericidal processes can cause tissue degeneration [13]. In cows with mastitis, serum lipid peroxidation levels were increased, and the level of blood glutathione peroxidase was decreased compared to the levels in healthy cows [14].

This study showed that MDA level was different among pathogens causing mastitis (Figure 1(B)). Characteristics of pathogens may be the reason for differences in oxidative environment in udders. In addition, the occurrence of mastitis is related to insufficient antioxidants such as glutathione peroxidase [14] and vitamin E. Deficiencies of antioxidants, either vitamin $\mathrm{E}$ or $\mathrm{Se}$, have been associated with increased incidence and severity of mastitis, increased number of clinical mastitis cases, and higher SCC both in milk of individual cows and in bulk tank milk [15]. The differences of MDA among pathogens might be due to the differences of NO production in infected quarters. Elevated NO is due to microbial products [16] such as lipopolysachharides (LPS) from the pathogen [17].

In this study, milk samples were selected from mastitis cows that were in high bulk somatic cell count farms. Therefore, the prevalence of mastitis occurring in these farms might cause problems in the mastitis control program. As a cross-sectional study design, it was difficult to demonstrate the causal relationship between levels of oxidative products and pathogens. However, the results from this study might be used as preliminary findings for further study on the production of oxidative products among bacterial infection and subsequent inflammatory process.

Minor pathogens were the predominant group of bacteria isolated from milk samples in this study. This is in agreement with other European reports [18]. In our study, 
CNS was found as the highest isolate from milk samples, in both subclinical and clinical mastitis quarters. In a study in Germany, Corynebacterium bovis and CNS were the predominant findings, accounting for $62.2 \%$ of the positive samples [19]. In Thailand, studies in subclinical mastitis showed that environmental streptococci were the most frequent isolated bacteria followed by CNS [2,3]. As all samples were collected in June, this may result in differences of pathogens. In summer, CNS was found to be the most prevalence in Thailand [20], the same as in the United States [21,22].

As expected, Strep. uberis had the highest percentage among the environmental pathogens [23,24]. Environmental streptococci are in the environment surrounding cows, including bedding, fences, stalls, cow skin and feces, and this pathogen was found as the most prevalent in tropical countries $[2,3,25]$. In addition, coliform bacteria were a high percentage of environmental pathogens. These pathogens are sometimes suspected by dairy producers and their advisors to be likely causes of increased mastitis and SCC in herds. The intramammary infection caused by Gram-negative bacteria are of a relatively short duration and are not always detected by milk culture when present [26]; therefore, the number of new intramammary infections may be underestimated by whole-herd surveys at a given point in time.

\section{CONCLUSION}

In conclusion, severity of mastitis results in differences of MDA in milk. The higher severity causes higher oxidative stress levels. Bacterial isolates in milk are different levels of MDA. In this study, we found that Stephyolococcus uberis and coagulase negative staphylococci increased the level of MDA compared with healthy quarters.

\section{ACKNOWLEDGEMENTS}

This study is jointly funded by the Commission on Higher Education and Thailand Research Fund. The authors thank the staffs in biochemistry laboratory, Faculty of Medicine, Chiang Mai University for measurement of MDA, and Julanee Thaboonpeng for bacterial identification.

\section{REFERENCES}

[1] Bradley, A.J. (2002) Bovine mastitis: An evolving disease. Veterinary Journal, 164, 116-128. doi:10.1053/tvj1.2002.0724

[2] Suriyasathaporn, W. (2010) Milk quality and antimicrobial resistance against mastitis pathogens after changing from a conventional to an experimentally organic dairy farm. Asian-Australasian Journal of Animal Science, 23, 659-664.

[3] Suriyasathaporn, W. (2011) Epidemiology of subclincal mastitis and their antibacterial susceptibility in smallholder dairy farms, Chiang Mai Province, Thailand. Journal of Animal and Veterinary Advances, 10: 316-321. doi:10.3923/javaa.2011.316.321

[4] Nathan, C. and Xie, Q.W. (1994) Regulation of biosynthesis of nitric oxide. Journal of Biology and Chemistry, 269, 13725-13728.

[5] Suriyasathaporn, W., Heuer, C., Noordhuizen-Stassen, E.N. and Schukken, Y.H. (2000) Hyperketonemia and the impairment of udder defense: A review. Veterinary $R e$ search, 31, 397-412. doi:10.1051/vetres:2000128

[6] Suriyasathaporn, W., Vinitketkumnuen, U., Chewonarin, T., Boonyayatra, S., Kreausukon, K and Schukken, Y.H. (2006) Higher somatic cell counts resulted in higher malondialdehyde concentrations in raw cows' milk. International Dairy Journal, 16, 1088-1091.

[7] Suriyasathaporn, W., Vinitketkumnuen, U. and Chewonarin, T. (2010) Relationships among malondialdehyde, milk compositions, and somatic cell count in milk from bulk tank. Songklanakarin Journal of Science and Technology, 32, 23-26.

[8] Suriyasathaporn, W., Vinitketkumnuen, U., Chewonarin, T., Chupia, V. and Pinyopummintr, T. (2009) The indicative influence of oxidative stress on low milk yields in dairy cattle. Thai Journal of Veterinary Medicine, 39, 237-243.

[9] Nation Mastitis Council (1999) Laboratory handbook on bovine mastitis. NMC Inc., Madison.

[10] Santos, M.T., Valles, J., Aznar, J. and Vilches, J. (1980) Determination of plasma malondialdehyde-like materials and its clinical application in stroke patients. Journal of Clinical Pathology, 33, 973-976.

doi:10.1136/jcp.33.10.973

[11] Radostits, O.M., Gay, C.C., Blood, D.C. and Hinchcliff, K.W. (2000) Bovine mastitis: In: Veterinary Medicine A Textbook of the Diseases of Cattle, Sheep, Pigs, Goats and Horses. 9th Edition, W.B. Saunders Company Ltd., London.

[12] Babior, B.M. (1999) NADPH oxidase: An update. Blood, 93, 1464-1476.

[13] Cohen, M.S. (1994) Molecular events in the activation of human neutrophils for microbial killing. Clinical Infectious Disease, 18, S170-S179. doi:10.1093/clinids/18.Supplement_2.S170

[14] Atroshi, F., Parantainen, J., Sankari, S., Jarvinen, M., Lindberg, L.A. and Saloniemi, H. (1996) Changes in inflammation-related blood constituents of mastitic cows. Veterinary Research, 27, 125-132.

[15] Smith, K. L., Hogan, J.S., and Weiss, W.P. (1997) Dietary vitamin $\mathrm{E}$ and selenium affect mastitis and milk quality. Journal of Animal Science, 75, 1659-1665.

[16] Melek, I. M., Erdogan, S., Celik, S., Aslantas, O. and Duman, T. (2006) Evaluation of oxidative stress and inflammation in long term Brucella melitensis infection. Molecular and Cellular Biochemistry, 293, 203-209. doi:10.1007/s11010-006-9243-2

[17] Lopez-Urrutia, L., Alonso, A., Nieto, M.L., Bayon, Y., Orduna, A. and Sanchez Crespo, M. (2000) Lipopolysac- 
charides of Brucella abortus and Brucella melitensis induce nitric oxide synthesis in rat peritoneal macrophages. Infection and Immunity, 68, 1740-1745. doi:10.1128/IAI.68.3.1740-1745.2000

[18] Pitkala, A., Haveri, M., Pyorala, S., Myllys, V. and Honkanen-Buzalski, T. (2004) Bovine mastitis in Finland 2001-Prevalence, distribution of bacteria and antimicrobial resistance. Journal of Dairy Science, 87, 24332441. doi:10.3168/jds.S0022-0302(04)73366-4

[19] Tenhage, B.A., Köster, G., Wallmann, J. and Heuwieser, W. (2006) Prevalence of mastitis pathogens and their resistance against antimicrobial agents in dairy cows in Brandenburg, Germany. Journal of Dairy Science, 89, 2542-2551. doi:10.3168/jds.S0022-0302(06)72330-X

[20] Chaisri, W., Okonogi, S., Kreausukon, K., Pinyopummintr, T. and Suriyasathaporn, W. (2010) Effects of medium and high discomfort periods during dry environment on either pathogens causing subclinical mastitis or antimicrobial resistance of environmental Streptococci and coagulase-negative Staphylococci. Chiang Mai University Journal of Natural Sciences, 9, 217-230.

[21] Makovec, J.A. and Ruegg, P.L. (2003) Results of milk samples submitted for microbiological examination in Wisconsin from 1994 to 2001. Journal of Dairy Science, 86, 3466-3472. doi:10.3168/jds.S0022-0302(03)73951-4
[22] Wilson, D.J., Gonzalez, R.N. and Das, H.H. (1997) Bovine mastitis pathogens in New York and Pennsylvania: Prevalence and effects on somatic cell count and milk production. Journal of Dairy Science, 80, 2592-2598. doi:10.3168/jds.S0022-0302(97)76215-5

[23] Morin, D., Mallard, C., Roberson, J., Timms, L., Fox, L., Erskine, R., Hurley, W. and Constable, P. (2001) Dynamics of environmental streptococcus mastitis in six US dairy herds. Proceedings of 2nd International Symposium of Mastitis and Milk Quality, National Mastitis Council, Madison, 150-154.

[24] Poelarends, J.J., Hogeveen, H., Sampimon, O.C. and Sol, J. (2001) Monitoring subclinical mastitis in Dutch dairy herds. Proceedings of 2nd International Symposium of Mastitis and Milk Quality, National Mastitis Council, Madison, 145-149.

[25] Ajariyakhajorn, K., Inchaisri, C., Boonserm, T. and Samngamnim, S. (2000) Identification of coagulase negative staphylococci causing subclinical mastitis and their antimicrobial resistance patterns. Thai Journal of Veterinary Medicine, 30, 23-33.

[26] Sears, P. M., R. N. Gonzalez, R.N., Wilson, D.J. and Han, H.R. (1993) Procedures for mastitis diagnosis and control. Veterinary Clinics of North America, 9, 445-468. 